\title{
IMBAS PERATURAN PEMERINTAH NOMOR 49 TAHUN 2018 DALAM PENATAAN PEGAWAI DI INSTANSI PEMERINTAH ${ }^{1}$
}

\author{
Henny Juliani \\ Fakultas Hukum Universitas Diponegoro \\ Jl. Prof. Sudarto, S.H. Tembalang, Semarang 50274 \\ hennyjuliani.fhundip@gmail.com
}

\begin{abstract}
This research was conducted to determine impact of PP Number 49 of 2018 concerning PPPK Management in structuring employees in government agencies. The approach used is normative juridical, while its specification is descriptive analytic. The results showed that impact of implementation of PP 49 of 2018 provide significant impact namely forbidding promoting contract workers as ASN officers, including for replacing resign or fired honorary workers solution to fulfill employee demand is conducted by open honorary workers recruitment to obtain professional ASN. ASN professionalism demand through JF PPPK selection as bureaucation structuring form in create good governance should be conducted by fair regulation policy for K1 and $K 2$ contract workers who has worked for government.
\end{abstract}

Keywords: Employee Management; PPPK; Government Agencies.

\begin{abstract}
Abstrak
Penelitian ini dilakukan untuk mengetahui imbas PP Nomor 49 Tahun 2018 tentang Manajemen PPPK dalam penataan pegawai di instansi pemerintah. Metode pendekatan yang digunakan adalah yuridis normatif, sedangkan spesifikasi penelitiannya adalah deskriptif analitis. Hasil penelitian menunjukkan bahwa imbas berlakunya PP Nomor 49 Tahun 2018 memberi dampak yang signifikan yaitu larangan pengangkatan tenaga honorer untuk pengisian jabatan ASN termasuk pengangkatan dalam rangka mengganti tenaga honorer yang berhenti atau diberhentikan. Solusi pengisian kebutuhan pegawai di instansi Pemerintah dilakukan melalui rekrutmen PPPK secara terbuka agar diperoleh ASN yang profesional. Tuntutan profesionalitas ASN melalui seleksi JF PPPK sebagai bentuk penataan birokrasi dalam mewujudkan good governance harus dilakukan dengan kebijakan regulasi yang berkeadilan bagi tenaga kontrak K1 dan K2 yang selama ini telah bekerja di instansi Pemerintah.
\end{abstract}

Kata kunci: Penataan Pegawai; PPPK; Instansi Pemerintah.

\footnotetext{
${ }^{1}$ Penelitian dibiayai oleh Dana Selain APBN Fakultas Hukum Universitas Diponegoro Tahun Anggaran 2020.
} 


\section{A. Pendahuluan}

Administrasi pemerintahan sebagai tata laksana dalam pengambilan keputusan dan/atau tindakan oleh badan/pejabat pemerintahan dibutuhkan dalam penyelenggaraan fungsi pemerintahan, yang berupa fungsi pengaturan, pelayanan, pembangunan, pemberdayaan, dan perlindungan. Hal tersebut dapat terlaksana apabila didukung oleh birokrasi yang andal, berupa sumber daya manusia (SDM) aparatur/pegawai Aparatur Sipil Negara (ASN) yang berintegritas dan bertanggung jawab dalam melaksanakan fungsi-fungsi pemerintahan tersebut. Terwujudnya ketersediaan SDM Aparatur menjadi faktor penting dalam memenuhi tuntutan masyarakat akan pelayanan publik yang cepat dan profesional agar roda pemerintahan dapat berjalan secara optimal sesuai tuntutan dan harapan masyarakat. Ketersediaan Pegawai Negeri Sipil (PNS) sebagai SDM Aparatur dirasakan masih kurang. Kondisi tersebut membuat pejabat pemerintahan yang berwenang melaksanakan kewenangan diskresi untuk memenuhi kekurangan tersebut melalui perekrutan tenaga honorer. Hal ini dimungkinkan karena pengadaan calon PNS tidak sebanding dengan jumlah yang dibutuhkan oleh instansi pemerintah. Oleh karena itu tidak dapat dipungkiri bahwa keberadaan tenaga honorer memiliki kontribusi penting untuk mengisi kekurangan jumlah PNS dalam penyelenggaraan pelayanan publik. Untuk itu diperlukan regulasi dalam penataan tenaga honorer yang eksisting sangat besar jumlahnya dan upaya pemenuhan kebutuhan SDM aparatur yang profesional, yang diperoleh secara selektif dan kompetitif.

Undang Undang Dasar Negara Republik Indonesia Tahun 1945 Pasal 1 ayat (3) menyatakan bahwa: "Negara Indonesia adalah negara hukum." Sebagai negara hukum, maka setiap penyelenggaraan urusan pemerintahan haruslah berdasarkan pada hukum yang berlaku. Kekuasaan negara dan penyelenggaraan kekuasaan tersebut dalam segala bentuknya dilakukan di bawah kekuasaan hukum. Dalam negara hukum, hukum ditempatkan sebagai aturan main dalam penyelenggaraan kenegaraan, pemerintahan, dan kemasyarakatan, sementara tujuan hukum itu sendiri antara lain “... opgelegd om de samenleving vreedzaam, rechtvaardig, en doelmatig te ordenen... (diletakkan untuk menata masyarakat yang damai, adil dan bermakna). Artinya sasaran dari negara hukum adalah terciptanya kegiatan kenegaraan, pemerintahan, dan kemasyarakatan yang bertumpu pada keadilan, kedamaian, dan kemanfaatan, atau kebermaknaan. Dalam negara hukum, eksistensi hukum dijadikan sebagai instrumen dalam menata kehidupan kenegaraan, pemerintahan, dan kemasyarakatan (Ridwan H.R., 2014). Sasaran negara hukum diwujudkan melalui instrumen pemerintahan sebagai sarana untuk melaksanakan tugas-tugas pemerintahan, yang antara lain berupa instrumen peraturan kebijakan. Instrumen peraturan kebijakan ini diperoleh pemerintah melalui kewenangan diskresi yang melekat pada pejabat pemerintahan. Freies ermessen atau diskresi dimiliki oleh setiap pemegang jabatan atau pejabat pemerintahan untuk mengambil kebijakan strategis berupa keputusan atau tindakan dalam mengatasi persoalan konkret yang mendesak yang membutuhkan penanganan segera. Dalam negara hukum, pertanggungjawaban pejabat pemerintahan merupakan suatu keharusan. Pengecualian terhadap asas legalitas dengan menggunakan asas diskresi tetap harus dapat dipertanggungjawabkan, karena tanpa pertanggungjawaban maka tindakan diskresi pemerintah dapat berpotensi disalahgunakan (Juliani, 2018). Diskresi dalam penyelenggaraan pemerintahan seyogianya bersifat situasional atau sesuai keadaan yang tepat. Diskresi adalah kekuasaan yang mengandung pengertian sangat khusus, yaitu pengecualian dari situasi normal dimana tuntutan mengenai tindakan yang harus dilakukan oleh pemerintah sudah tercakup dalam ketentuan peraturan perundangundangan. Dalam situasi normal maka jenis kekuasaan yang berlaku bagi pemerintah 
adalah kekuasaan atau kewenangan terikat (Darumurti, 2016). Pelaksanaan tugas dan fungsi pemerintahan tersebut memerlukan dukungan SDM aparatur (ASN) sebagai birokrat yang bekerja pada instansi pemerintah.

Birokrasi adalah kata yang lekat dengan mesin kerja pemerintah. Meskipun sesungguhnya birokrasi adalah salah satu tipe organisasi, akan tetapi secara awam lebih merefleksikan organisasi pemerintah (Wicaksono, 2014). Max Weber sebagaimana dikutip oleh Amy Y.S. Rahayu dan Vishnu Juwono mengidentifikasikan beberapa karakteristik birokrasi yang ideal, profesional dan rasional dijalankan. Karakteristik tersebut di antaranya sebagai sebuah sistem administrasi publik yang rasional berdasarkan aturan tertulis, dikelola secara impersonal dan dengan pembagian tugas yang jelas. Para birokrat yang dipilih untuk jabatan pimpinan berdasarkan tingkat kompetensi, bukan kolusi. Selain itu Weber juga menekankan pentingnya pendidikan dan birokrat seharusnya merupakan sebuah profesi dengan tingkat keahlian yang tinggi. Sehingga Weber berkesimpulan bahwa birokrasi terdiri dari struktur yang hierarkis namun profesional, taat kepada sistem hukum, bersifat impersonal, menganut sistem meritokrasi yang terdiri dari para aparatur negara dengan sebuah keahlian tertentu (Rahayu \& Juwono, 2019). Menurut Sultana, birokrasi merupakan jenis pemerintahan yang ideal dan terkait dengan good governance (Rahayu \& Juwono, 2019). Quah berpendapat bahwa reformasi birokrasi diterapkan berdasarkan perencanaan untuk mewujudkan good governance dalam jalannya birokrasi (Rahayu \& Juwono, 2019). Sedangkan Ilyas menyatakan bahwa good governance sangat bergantung pada birokrasi yang jujur dan kuat. Birokrasi mengharuskan para birokrat untuk mematuhi arahan pejabat atasan, dengan tetap memperhatikan peraturanperaturan (Rahayu \& Juwono, 2019). Bevir mendefinisikan good governance sebagai pengelolaan negara dengan memperhatikan nilai-nilai demokratis, terbuka, dan professional (Rahayu \& Juwono, 2019). Menurut Sri Nurhari Susanto, menciptakan pemerintah (government) yang baik, maka tata kelola pemerintahan (governance) yang baik belum tentu akan tercipta, tetapi jika tata kelola pemerintahan (governance) yang baik tercipta, maka pemerintah (government) yang baik pasti akan tercipta juga (Susanto, 2019).

Penelitian tentang Pegawai Pemerintah dengan Perjanjian Kerja (PPPK) telah banyak dilakukan setelah diundangkannya UU Nomor 5 Tahun 2014 tentang Aparatur Sipil Negara (ASN) dan PP Nomor 49 Tahun 2018 tentang Manajemen PPPK. Salah satunya adalah artikel yang termuat dalam jurnal Administrative Law \& Governance, Volume 2, Issue 2, June 2019 yang berjudul: Diskresi dalam Rekrutmen Pegawai Non Pegawai Negeri Sipil Setelah Pemberlakuan Peraturan Pemerintah Nomor 49 Tahun 2018 tentang Manajemen Pegawai Pemerintah dengan Perjanjian Kerja, yang ditulis oleh Henny Juliani. Penelitian tersebut dilakukan untuk mengetahui akibat hukum yang timbul dari diskresi pejabat pemerintahan dalam perekrutan pegawai tidak tetap/non-PNS (honorer/kontrak) setelah berlakunya PP Nomor 49 Tahun 2018 tentang Manajemen PPPK.

Peraturan pelaksanaan dari PP Nomor 49 Tahun 2018 tentang Manajemen PPPK telah banyak dikeluarkan oleh pemerintah sebagai upaya dalam memberikan solusi terhadap tuntutan profesionalitas ASN, namun permasalahan muncul berkaitan dengan bagaimana penanganan tenaga honorer yang eksisting di banyak instansi pemerintah baik pusat maupun daerah yang selama ini digunakan sebagai alternatif penyediaan SDM aparatur dalam menopang kelancaran administrasi pemerintahan. Bagaimana kebijakan yang ditempuh pemerintah untuk mengatasi hal tersebut sebagai imbas dari PP Nomor 49 Tahun 2018. Di sisi lain untuk mewujudkan PPPK yang berkualitas, berkompeten, berdisiplin, profesional dalam melaksanakan tugas dan fungsinya perlu dilakukan rekrutmen secara terbuka dan kompetitif agar mendapatkan 
PPPK yang andal. Hal tersebut membuat pemerintah mengeluarkan berbagai peraturan kebijakan sebagai pelaksanaan PP Nomor 49 Tahun 2018. Oleh karena itu tujuan penelitian ini adalah untuk mengetahui sejauh mana imbas PP Nomor 49 Tahun 2018 tentang Manajemen PPPK dalam penataan pegawai di instansi pemerintah.

\section{B. Metode Penelitian}

Penelitian ini menggunakan pendekatan yuridis normatif, karena masalah yang akan diteliti tersebut berhubungan erat dengan law in books. Penelitian hukum normatif merupakan penelitian kepustakaan, yaitu penelitian yang dilakukan untuk mengkaji hukum berdasarkan data sekunder. Ronny Hanitijo Soemitro menyatakan bahwa, data sekunder di bidang hukum (dipandang dari sudut kekuatan mengikatnya), dapat dibedakan menjadi bahan-bahan hukum primer, bahan-bahan hukum sekunder, dan bahan hukum tersier (Soemitro, 1994).

Spesifikasi penelitian yang digunakan dalam penelitian ini adalah deskriptif analitis dimana hasil penelitian yang diperoleh dari penelitian ini digambarkan secara rinci, sistematis, dan menyeluruh berkaitan dengan peraturan perundang-undangan yang berlaku dan teori-teori hukum untuk mendukung penyelesaian permasalahan, yang kemudian akan dilakukan analisa secara kritis terhadap permasalahan tersebut. Bahan-bahan tersebut selanjutnya dianalisis secara kualitatif.

\section{Hasil dan Pembahasan}

\section{Urgensi SDM Aparatur yang Profesional dalam Pelayanan Publik}

Berdasarkan data, jumlah PNS per Juni 2020 sebanyak 4.121.176 orang, yang tersebar di instansi daerah sebanyak 3.174 .570 orang $(77 \%)$ dan di instansi pusat sebanyak 946.606 orang (23\%). Jumlah tersebut mengalami penurunan 1,62\% apabila dibandingkan dengan jumlah PNS pada bulan Desember 2019 yaitu sebanyak 4.189.121 orang. Penurunan ini terjadi sejak tahun 2016 karena pemerintah menetapkan moratorium pada tahun 2015 dan 2016. Dari 4.121.176 orang, sebanyak 147.524 pegawai tersebut pada tahun 2020 diprediksi memasuki usia pensiun (Badan Kepegawaian Negara, 2020). Jumlah PNS yang mengalami penurunan tersebut menunjukkan realita yang terjadi di banyak instansi pemerintah, bahwa jumlah PNS untuk melaksanakan pelayanan publik dirasakan masih kurang karena hanya tersedia 4,2 juta birokrat dibandingkan dengan 270 juta penduduk yang dilayani.

Menurut Undang-Undang Nomor 5 Tahun 2014 tentang Aparatur Sipil Negara, ASN adalah profesi bagi pegawai negeri sipil (PNS) dan pegawai pemerintah dengan perjanjian kerja (PPPK) yang bekerja pada instansi pemerintah. Pegawai ASN tersebut diangkat oleh pejabat pembina kepegawaian (PPK) dan diserahi tugas dalam suatu jabatan pemerintahan atau diserahi tugas negara lainnya dan digaji berdasarkan peraturan perundang-undangan. Pegawai ASN berkedudukan sebagai unsur aparatur negara, yang berfungsi sebagai pelaksana kebijakan publik, pelayan publik, dan perekat serta pemersatu bangsa. Sebagai suatu profesi, maka manajemen ASN diselenggarakan berdasarkan sistem merit. Manajemen ASN tersebut meliputi manajemen PNS dan manajemen PPPK. Manajemen ASN merupakan suatu model pengelolaan ASN untuk menghasilkan pegawai ASN yang profesional. Barang dan jasa publik hendaknya dapat dikelola secara efisien dan efektif. Sedangkan konsekuensi dari pengelolaan tersebut menjadi tanggung jawab birokrasi. Dengan demikian peran pemerintah yang sangat strategis tersebut akan banyak ditopang oleh bagaimana birokrasi publik mampu melaksanakan tugas dan fungsinya. Pelayanan yang diberikan oleh birokrat ditafsirkan sebagai kewajiban, bukan hak karena mereka diangkat oleh pemerintah untuk melayani masyarakat, oleh karena itu harus dibangun komitmen yang kuat untuk melayani sehingga pelayanan akan dapat menjadi lebih responsif terhadap kebutuhan masyarakat dan dapat merancang 
model pelayanan yang lebih kreatif serta lebih efisien (Abbas \& Sadat, 2020).

Undang-Undang Nomor 5 Tahun 2014 tentang ASN tersebut menjadi dasar hukum dalam membangun ASN yang profesional berdasarkan sistem merit sebagai bagian dari reformasi birokrasi. Hal tersebut sejalan dengan pendapat Ridwan H.R. bahwa dalam negara hukum, hukum ditempatkan sebagai aturan main dalam penyelenggaraan kenegaraan, pemerintahan, dan kemasyarakatan, sementara tujuan hukum itu sendiri antara lain “... opgelegd om de samenleving vreedzaam, rechtvaardig, en doelmatig te ordenen... (diletakkan untuk menata masyarakat yang damai, adil dan bermakna). Artinya sasaran dari negara hukum adalah terciptanya kegiatan kenegaraan, pemerintahan, dan kemasyarakatan yang bertumpu pada keadilan, kedamaian, dan kemanfaatan, atau kebermaknaan. Dalam negara hukum, eksistensi hukum dijadikan sebagai instrumen dalam menata kehidupan kenegaraan, pemerintahan, dan kemasyarakatan (Ridwan H.R., 2014).

Birokrasi adalah kata yang lekat dengan mesin kerja pemerintah. Meskipun sesungguhnya birokrasi adalah salah satu tipe organisasi, akan tetapi secara awam lebih merefleksikan organisasi pemerintah (Wicaksono, 2014). Max Weber sebagaimana dikutip oleh Amy Y.S. Rahayu dan Vishnu Juwono mengidentifikasikan beberapa karakteristik birokrasi yang ideal, profesional dan rasional dijalankan. Karakteristik tersebut di antaranya sebagai sebuah sistem administrasi publik yang rasional berdasarkan aturan tertulis, dikelola secara impersonal dan dengan pembagian tugas yang jelas. Para birokrat yang dipilih untuk jabatan pimpinan berdasarkan tingkat kompetensi, bukan kolusi. Selain itu Weber juga menekankan pentingnya pendidikan dan birokrat seharusnya merupakan sebuah profesi dengan tingkat keahlian yang tinggi. Sehingga Weber berkesimpulan bahwa birokrasi terdiri dari struktur yang hierarkis namun profesional, taat kepada sistem hukum, bersifat impersonal, menganut sistem meritokrasi yang terdiri dari para aparatur negara dengan sebuah keahlian tertentu (Rahayu \& Juwono, 2019). Menurut Sultana, birokrasi merupakan jenis pemerintahan yang ideal dan terkait dengan good governance. Sedangkan Quah berpendapat bahwa reformasi birokrasi diterapkan berdasarkan perencanaan untuk mewujudkan good governance dalam jalannya birokrasi (Rahayu \& Juwono, 2019).

Penjelasan Umum PP Nomor 49 Tahun 2018 tentang Manajemen PPPK menyatakan bahwa untuk dapat menjalankan tugas pelayanan publik, tugas pemerintahan, dan tugas pembangunan tertentu, PPPK harus memiliki profesi dan manajemen PPPK yang berdasarkan pada sistem Merit atau perbandingan antara kualifikasi, kompetensi, dan kinerja yang dibutuhkan oleh jabatan dengan kualifikasi, kompetensi, dan kinerja yang dimiliki oleh calon dalam rekrutmen, pengangkatan, dan penempatan sejalan dengan tata kelola pemerintahan yang baik. Oleh karena itu diperlukan reformasi dalam tata kelola pemerintahan terhadap SDM aparatur. Reformasi dalam perpektif Administrasi Publik, lebih dikenal dengan istilah reformasi administrasi (administrative reform) yang diperkenalkan yang menekankan pentingnya transformasi nilainilai baru ke dalam birokrasi, sehingga birokrasi pemerintah dapat berkinerja baik dalam penyelenggaraan pemerintahan nasional, maupun daerah dalam mewujudkan pelayanan publik yang berkualitas, sebagai syarat terciptanya kepuasan pelanggan (customer satisfaction) atas semua jenis layanan yang diterima dari pejabat publik (Haning, 2018).

Berdasarkan hal tersebut maka pemerintah berharap dapat memperoleh pegawai PPPK yang profesional berdasarkan pada sistem Merit melalui proses seleksi administrasi maupun seleksi kompetensi yang meliputi seleksi manajerial, teknis, maupun sosial kultural. Dengan demikian berdasarkan PP tersebut pegawai honorer tidak dapat secara otomatis diangkat sebagai Calon PPPK, namun untuk dapat diangkat 
sebagai Calon PPPK maka pegawai honorer tersebut harus memenuhi syarat dan lolos seleksi administrasi maupun seleksi kompetensi, yang pelaksanaannya mirip dengan pelaksanaan seleksi CPNS. Hal tersebut sesuai dengan pendapat Bevir yang mendefinisikan good governance sebagai pengelolaan negara dengan memperhatikan nilai-nilai demokratis, terbuka, dan professional (Rahayu \& Juwono, 2019). Menurut Sri Nurhari Susanto, menciptakan pemerintah (government) yang baik, maka tata kelola pemerintahan (governance) yang baik belum tentu akan tercipta, tetapi jika tata kelola pemerintahan (governance) yang baik, maka pemerintah (government) yang baik pasti akan tercipta juga (Susanto, 2019).

\section{Implikasi Yuridis PP Nomor 49 Tahun 2018 dalam Penataan Pegawai}

Undang-Undang Nomor 5 Tahun 2014 tentang Aparatur Sipil Negara menjadi dasar pengaturan kepegawaian di Indonesia. Undang-Undang tersebut mencabut dan menyatakan tidak berlaku Undang-Undang Nomor 8 Tahun 1974 tentang Pokok-Pokok Kepegawaian sebagaimana telah diubah dengan Undang-Undang Nomor 43 Tahun 1999. Kedua undang-undang tersebut memiliki perbedaan mendasar dalam hal pengaturan mengenai jenis-jenis pegawai dan ketentuan-ketentuan lainnya.

Pasal 1 angka 1 Undang-Undang Nomor 5 Tahun 2014 menyatakan bahwa ASN adalah profesi bagi PNS dan PPPK yang bekerja pada instansi pemerintah. Berdasarkan hal tersebut, maka jenis pegawai ASN terdiri atas PNS dan PPPK (Pasal 6). Perbedaan antara PNS dengan PPPK adalah bahwa PNS merupakan pegawai ASN yang diangkat secara tetap, sedangkan PPPK merupakan pegawai ASN yang diangkat berdasarkan perjanjian kerja untuk jangka waktu tertentu. Keduanya memiliki kedudukan sebagai unsur aparatur negara yang melaksanakan tugas pemerintahan.

Hal tersebut berbeda dengan jenis pegawai yang diatur dalam Undang-Undang
Nomor 43 Tahun 1999. Pasal 2 ayat (3) menyatakan bahwa di samping pegawai negeri, pejabat yang berwenang dapat mengangkat pegawai tidak tetap (PTT), yang diangkat untuk jangka waktu tertentu guna melaksanakan tugas pemerintahan dan pembangunan yang bersifat teknis profesional dan administrasi sesuai dengan kebutuhan dan kemampuan organisasi. PTT tidak berkedudukan sebagai Pegawai Negeri. Ketentuan tersebut menjadi dasar pengangkatan $\mathrm{PTT} /$ tenaga honorer untuk dipekerjakan di instansi pemerintah oleh pejabat pemerintahan dengan menggunakan kewenangan diskresi dengan maksud agar kebutuhan pegawai yang bersifat mendesak dapat terpenuhi. Hal tersebut dilakukan agar fungsi pemerintahan bisa berjalan, karena apabila berharap pada ketersediaan pegawai negeri maka pelaksanaan fungsi pemerintahan akan mengalami hambatan. Oleh karena itu maka kebijakan pengangkatan PTT/tenaga honorer tergantung pada diskresi pejabat pemerintahan. Diskresi dalam penyelenggaraan pemerintahan seyogianya bersifat situasional atau sesuai keadaan yang tepat. Diskresi adalah kekuasaan yang mengandung pengertian sangat khusus, yaitu pengecualian dari situasi normal di mana tuntutan mengenai tindakan yang harus dilakukan oleh pemerintah sudah tercakup dalam ketentuan peraturan perundangundangan. Dalam situasi normal maka jenis kekuasaan yang berlaku bagi pemerintah adalah kekuasaan atau kewenangan terikat (Darumurti, 2016). Diskresi (freies ermessen) merupakan kewajiban pemerintah dalam sebuah negara kesejahteraan (welfare state), yang mana tugas pemerintah yang utama dalam negara kesejahteraan adalah memberikan pelayanan umum atau mengusahakan kesejahteraan bagi warga negara. Diskresi yang ada di Indonesia muncul bersamaan dengan adanya pemberian tugas bagi pemerintah untuk melaksanakan dan merealisasikan tujuan negara Indonesia (Sihotang, Pujiyono, \& Sa'adah, 2017). Dalam praktek, kebijakan strategis rekrutmen/pengangkatan tenaga 
honorer tersebut sering kali dilakukan oleh pejabat pemerintahan tidak secara terbuka bahkan sarat dengan nuansa kolusi dan nepotisme sehingga sulit mendapatkan tenaga honorer yang berkompeten, berintegritas dan profesional. Hal tersebut justru bertentangan dengan makna diskresi itu sendiri, karena sesungguhnya Freies ermessen atau diskresi dimiliki oleh setiap pemegang jabatan atau pejabat pemerintahan untuk mengambil kebijakan strategis berupa keputusan atau tindakan dalam mengatasi persoalan konkret yang mendesak yang membutuhkan penanganan segera. Dalam negara hukum, pertanggungjawaban pejabat pemerintahan merupakan suatu keharusan. Pengecualian terhadap asas legalitas dengan menggunakan asas diskresi tetap harus dapat dipertanggungjawabkan, karena tanpa pertanggungjawaban maka tindakan diskresi pemerintah dapat berpotensi disalahgunakan (Juliani, 2018).

PTT/tenaga honorer banyak digunakan dan tersebar di instansi pemerintah baik di pusat maupun daerah. Mereka telah bekerja selama bertahun-tahun dengan berdasar pada kontrak yang diperbaharui setiap tahun, dan beban kerja mereka yang relatif sama bahkan bisa berlebih apabila dibandingkan dengan PNS namun penghasilan mereka berbeda. Saat ini tercatat sebanyak 438.590 tenaga honorer. Dari jumlah tersebut 157.210 atau 35,84\% berprofesi sebagai guru (Faqir, 2020) . Tenaga honorer yang bekerja di instansi pemerintah terdiri dari beberapa jenis, yaitu: tenaga honorer kategori 1 (K1), tenaga honorer kategori 2 (K2), dan tenaga honorer non-kategori.

Implikasi yang ditimbulkan kemudian adalah semakin membengkaknya beban kerja PTT daripada PNS. Hal inilah yang tentunya membuat ranah kinerja pegawai tidak tetap justru berada di dua ranah antara informal maupun formal dengan porsi tanggung jawab yang cukup besar pula. Maka tidaklah mengherankan apabila PTT sering kali mendapat sebutan the real civil service ketimbang PNS yang selalu berdedikasi secara penuh dalam mengemban amanah tugas. Meskipun hingga saat ini belum ada kejelasan status kepegawaian maupun tunjangan dan gaji yang belum sesuai dengan beban kinerja (Lohida, 2015).

Masalah seputar penyelesaian honorer K2 pelik dan berliku. Sejak 2014 hingga saat ini, dari 438.590 honorer K2 yang masuk database Badan Kepegawaian Negara (BKN), baru terselesaikan sekitar 59.000 orang. Rinciannya, sekitar 8.000 orang diangkat menjadi PNS lewat tes dan 51.000 orang lolos seleksi PPPK (Pegawai Pemerintah dengan Perjanjian Kerja) (Jambiekspres, 2020).

Sejak tahun 2005 pemerintah telah berusaha menyelesaikan polemik penanganan tenaga honorer. Pada tahun 2005 pemerintah menetapkan PP Nomor 48 Tahun 2005 tentang Pengangkatan Tenaga Honorer Menjadi Calon PNS. PP tersebut telah diubah dengan PP Nomor 43 Tahun 2007 dan PP Nomor 56 Tahun 2012. PP tersebut memberikan kesempatan kepada tenaga honorer yang telah bekerja di instansi pemerintah diprioritaskan diangkat sebagai calon PNS secara otomatis. Menurut PP Nomor 48 Tahun 2005, tenaga honorer adalah seseorang yang melaksanakan tugas tertentu pada instansi pemerintah, yang penghasilannya berasal dari APBN atau APBD. Selanjutnya menindaklanjuti ketentuan yang diatur dalam PP Nomor 48 Tahun 2005, dikeluarkan Surat Edaran Menteri PAN dan RB Nomor 05 Tahun 2010 tentang Pendataan Tenaga Honorer yang Bekerja di Lingkungan Instansi Pemerintah. SE tersebut menjadi bentuk tertulis dari diskresi pemerintah dengan membagi tenaga honorer menjadi kategori 1 (Honorer K1) dan tenaga honorer kategori 2 (Honorer K2) yang penghasilannya dibiayai bukan dari APBN atau APBD, misalnya untuk guru digaji dari dana komite dan dana BOS. Dalam perkembangan selanjutnya terdapat jenis tenaga honorer non-kategori, yaitu tenaga honorer yang keberadaannya muncul setelah pendataan tahun 2005 dan pendataan ulang tahun 2010. Setelah berlakunya UU Nomor 5 Tahun 2014 dan PP Nomor 49 Tahun 2018 pengangkatan secara otomatis tenaga honorer menjadi PNS 
sudah tidak berlaku lagi, sehingga tenaga honorerpun tidak dapat diangkat secara otomatis sebagai PPPK karena untuk dapat diangkat sebagai calon PPPK maka tenaga honorer tersebut harus memenuhi syarat dan lolos seleksi administrasi maupun seleksi kompetensi, yang pelaksanaannya mirip dengan pelaksanaan seleksi CPNS. Ketentuan tersebut menimbulkan keresahan bagi tenaga honorer karena tidak ada lagi pengangkatan secara otomatis sebagaimana ketentuan PP Nomor 48 Tahun 2005 maupun SE MenPAN RB Nomor 05 Tahun 2010. Namun untuk mewujudkan SDM aparatur yang profesional berdasarkan sistem merit memang diperlukan reformasi manajemen PPPK.

Menurut Pasal 2 PP Nomor 49 Tahun 2018 tentang Manajemen PPPK dinyatakan bahwa jabatan ASN yang dapat diisi oleh PPPK adalah Jabatan Fungsional (JF) dan Jabatan Pimpinan Tinggi (JPT). Selain jabatan tersebut, maka Menteri dapat menetapkan jabatan lain yang dapat diisi oleh PPPK, namun jabatan tersebut bukan jabatan struktural walaupun menjalankan fungsi manajemen pada instansi pemerintah. Berdasarkan hal tersebut maka dikeluarkan Peraturan Presiden (Perpres) Nomor 38 Tahun 2020 tentang Jenis Jabatan yang Dapat Diisi oleh PPPK. Untuk JPT, yang dapat diisi oleh PPPK hanya JPT utama tertentu dan JPT madya tertentu. Selanjutnya dinyatakan bahwa Jabatan lain bukan JA atau bukan JPT pratama dapat disetarakan dengan JA atau JPT pratama sesuai dengan ketentuan peraturan perundang-undangan. Penetapan jabatan lain tersebut sangat dinantikan oleh tenaga honorer yang menduduki jabatan administrasi karena realita di lapangan masih banyak tenaga honorer yang bertugas bukan pada jabatan fungsional. Reformasi birokrasi melalui manajemen ASN memang mengarahkan pada pengisian jabatan fungsional namun tetap diperlukan solusi bagi pegawai eksisting yang masih menduduki jabatan administrasi.

Pasal 4 Perpres Nomor 38 Tahun 2020 menyebutkan kriteria JF yang dapat diisi oleh PPPK, yaitu sebagai berikut: a). Jabatan yang kompetensinya tidak tersedia atau terbatas di kalangan PNS; b). Jabatan yang diperlukan untuk percepatan peningkatan kapasitas organisasi; c). Jabatan yang diperlukan untuk percepatan pencapaian tujuan strategis nasional; d). Jabatan yang mensyaratkan sertifikasi teknis dari organisasi profesi; e). bukan Jabatan di bidang rahasia negara, pertahanan, keamanan, pengelolaan aparatur negara, kesekretariatan negara, pengelolaan sumber daya alam, pengelolaan keuangan negara, dan hubungan luar negeri; dan f). bukan Jabatan yang menurut ketentuan UndangUndang, Peraturan Pemerintah, dan Peraturan Presiden harus diisi oleh PNS.

Lampiran Perpres Nomor 38 Tahun 2020 menyebutkan adanya 147 jenis jabatan fungsional yang dapat diisi oleh PPPK. Ketentuan tersebut ditindaklanjuti dengan dikeluarkan Peraturan Menteri PAN dan RB (PerMenPAN RB) Nomor 72 Tahun 2020 yang mengubah PerMen PAN RB Nomor 2 Tahun 2019 tentang Pengadaan PPPK untuk Guru, Dosen, Tenaga Kesehatan dan Penyuluh Pertanian. Dengan demikian untuk pengisian JF PPPK, sementara yang ditindaklanjuti melalui regulasi baru 4 jenis JF dari 147 jenis JF yang dapat diisi oleh PPPK. Regulasi lainnya perlu segera dikeluarkan agar kebutuhan JF PPPK yang lain dapat segera terpenuhi sehingga tugas pelayanan publik tidak terhambat.

Keberadaan PPPK sebagai ASN tidak sama dengan tenaga honorer yang bekerja di instansi pemerintah, karena selama ini tenaga honorer tidak memiliki jenjang karier dan tingkat kesejahteraan yang jelas, sedangkan Undang-Undang Nomor 5 Tahun 2014 dan PP Nomor 49 Tahun 2018 menjanjikan kejelasan jenjang karier dan kesejahteraan bagi PPPK. Menurut Pasal 22 Undang-Undang Nomor 5 Tahun 2014, PPPK berhak memperoleh: a). Gaji dan tunjangan; b). Cuti; c). Perlindungan; dan d). Pengembangan kompetensi. Pasal 20B (1) PerMen PAN RB Nomor 72 Tahun 2020 menyatakan bahwa PPPK yang telah diangkat diberikan gaji berdasarkan 
golongan gaji sesuai dengan ketentuan peraturan perundang-undangan dengan masa kerja 0 (nol) setelah perjanjian kerja ditandatangani. Menurut Pasal 38 ayat (2) PP Nomor 49 Tahun 2018, gaji dan tunjangan PPPK berlaku sesuai dengan ketentuan peraturan perundangan yang berlaku bagi PNS. Hal tersebut memberikan kepastian peningkatan kesejahteraan bagi PPPK. Ketentuan tersebut diatur lebih lanjut dalam Perpres Nomor 98 Tahun 2020 tentang Gaji dan Tunjangan bagi PPPK. PPPK yang diangkat untuk melaksanakan tugas jabatan diberikan Gaji yang besarannya didasarkan golongan dan masa kerja golongan. Termasuk juga berhak atas kenaikan gaji berkala atau kenaikan gaji istimewa. Selain gaji, PPPK juga memperoleh tunjangan yang terdiri atas: a). tunjangan keluarga; b). tunjangan pangan; c). tunjangan jabatan struktural; d). tunjangan jabatan fungsional; atau e). tunjangan lainnya. Gaji dan tunjangan bagi PPPK yang bekerja di Instansi Pusat dibebankan pada APBN, sedangkan gaji dan tunjangan bagi PPPK yang bekerja di Instansi Daerah dibebankan pada APBD. Ketentuan tersebut berdampak pada peningkatan alokasi anggaran belanja pegawai baik di pusat maupun di daerah. Peningkatan alokasi belanja pegawai (termasuk PPPK) tentu berpotensi menimbulkan tambahan beban baik dalam APBD secara langsung serta APBN secara tidak langsung. Karenanya perlu dipikirkan kondisi pengelolaan keuangan daerah dalam menyikapi mekanisme pengelolaan kepegawaian di daerah baik PNSD maupun PPPK. Jangan sampai beban kebutuhan belanja pegawai tersebut akhirnya menghilangkan alokasi APBD untuk tujuan investasi dan pembangunan di daerah. Secara umum, daerah dengan rasio belanja pegawai besar terhadap total belanja APBD nya, adalah daerah dengan peta kapasitas fiskal rendah (Provinsi Bengkulu, Provinsi DIY dan Provinsi NTT). Hanya Provinsi DKI Jakarta dan Provinsi Maluku Utara yang relatif memiliki kapasitas fiskal sangat tinggi dan tinggi. Untuk daerah dengan peta kapasitas fiskal yang rendah inilah yang wajib menjadi perhatian bersama jika nantinya harus mendanai kebutuhan PPPK di daerah masing-masing. Alternatif terbaik yang mungkin dilakukan adalah kebijakan realokasi belanja dengan menjaga keseimbangan antara jumlah kebutuhan pegawai baru dengan pegawai yang memasuki usia pensiun. Ke depannya, sekiranya Pemerintah Pusat wajib memberikan arahan dan petunjuk terkait kebijakan pengelolaan PNS dan PPPK ini dalam kerangka UU ASN. Perlu dihitung komposisi ideal jumlah kepegawaian PNS dan PPPK dengan mempertimbangkan kondisi fiskal yang ada serta tujuan meningkatkan pelayanan publik serta pembangunan di masing-masing daerah. Sentralisasi pengelolaan PNS dan PPPK sekiranya menjadi alternatif pilihan kebijakan yang perlu disimulasikan bersama-sama. Jangan sampai masingmasing daerah kemudian melakukan kebijakan kepegawaiannya secara terpisah, tak lama kemudian justru mengalami defisit pendanaan (Haryanto, 2015).

Masa perjanjian kerja PPPK diatur dalam Pasal 37 PP Nomor 49 Tahun 2018, yaitu "Masa hubungan perjanjian kerja bagi PPPK paling singkat 1 (satu) tahun dan dapat diperpanjang sesuai kebutuhan dan berdasarkan penilaian kinerja". Ketentuan tersebut ditindaklanjuti dengan PerMen PAN RB Nomor 70 Tahun 2020 tentang Masa Hubungan Perjanjian Kerja PPPK. Masa Hubungan Perjanjian Kerja adalah jangka waktu kebutuhan suatu Jabatan yang dapat diisi oleh PPPK dalam suatu instansi. PerMen PAN RB Nomor 70 Tahun 2020 menyatakan dalam Pasal 4 bahwa: Masa Hubungan Perjanjian Kerja untuk Jabatan Fungsional dan Jabatan lain yang bukan merupakan Jabatan struktural tetapi menjalankan fungsi manajemen pada Instansi Pemerintah ditetapkan dalam jangka waktu paling singkat 1 (satu) tahun dan paling lama 5 (lima) tahun sesuai dengan penyusunan kebutuhan ASN. Masa Hubungan Perjanjian Kerja untuk Jabatan Fungsional dapat diperpanjang untuk jangka 
waktu paling lama 5 (lima) tahun. Masa Hubungan Perjanjian Kerja untuk JPT utama tertentu dan JPT madya tertentu ditetapkan sesuai dengan ketentuan peraturan perundang-undangan. Perpanjangan masa hubungan perjanjian kerja untuk JPT utama tertentu dan JPT madya tertentu paling lama 5 (lima) tahun. Pasal 5 ayat (1) menyatakan bahwa Jangka waktu hubungan perjanjian kerja antara PPPK dengan PPK tidak melebihi batas waktu Masa Hubungan Perjanjian Kerja sebagaimana dimaksud dalam Pasal 4. Apabila ditelaah, maka ketentuan ini memberikan batasan waktu paling lama 10 (sepuluh) tahun bagi PPPK dengan kriteria tersebut di atas (JF dan jabatan lain) untuk bekerja pada instansi pemerintah dan selanjutnya diberhentikan karena jangka waktu perjanjian kerja berakhir atau terjadi pemutusan hubungan kerja. Hal tersebut berdampak pada ketidakpastian masa depan PPPK bahkan bertentangan dengan ketentuan masa hubungan perjanjian kerja bagi PPPK yang diatur dalam Undang-Undang Nomor 5 Tahun 2014 tentang ASN dan PP Nomor 49 Tahun 2018 tentang PPPK yang mengatur masa hubungan kerja bagi PPPK paling singkat 1 (satu) tahun dan dapat diperpanjang sesuai kebutuhan dan berdasarkan penilaian kinerja. Ketentuan untuk JPT utama dan JPT Madya tertentu memang seharusnya memiliki batasan waktu sebagaimana diatur dalam PerMen PAN RB Nomor 70 Tahun 2020 karena menduduki jabatan pimpinan tinggi. Perpanjangan hubungan perjanjian kerja bagi PPPK yang menduduki JPT Utama dan JPT Madya tertentu paling lama 5 (lima) tahun inipun tidak bertentangan dengan Undang-Undang Nomor 5 Tahun 2014 tentang ASN dan PP Nomor 48 Tahun 2019 tentang PPPK.

Imbas berlakunya PP Nomor 49 Tahun 2018 tentang Manajemen PPPK secara signifikan dapat dilihat bahwa sejak tanggal 28 November 2018 Pejabat Pembina Kepegawaian (PPK) atau pejabat lain selain PPK dilarang mengangkat pegawai non-PNS dan/atau non-PPPK untuk mengisi jabatan ASN. Larangan tersebut juga berlaku untuk pengangkatan dalam rangka mengganti pegawai non-PNS dan/atau non-PPPK yang berhenti/diberhentikan. Apabila ketentuan tersebut dilanggar, maka kepada PPK atau pejabat lain selain PPK akan dikenakan sanksi sesuai ketentuan peraturan perundang-undangan. Berdasarkan ketentuan tersebut, maka Pejabat Pemerintahan yang berwenang melakukan pengangkatan pegawai sebagaimana tersebut di atas tidak lagi dapat menggunakan kewenangan diskresi dalam pengangkatan pegawai honorer. Apabila unit kerja instansi Pemerintah masih membutuhkan pegawai untuk mengisi kekosongan jabatan ASN, maka dapat mengajukan kebutuhan pegawai melalui pengajuan usul formasi CPNS dan/atau CPPPK setelah melakukan penataan/penempatan pegawai pada peta jabatan masing-masing (Juliani, 2019).

Ketentuan tentang larangan pengangkatan tenaga honorer sebenarnya telah termuat juga dalam PP Nomor 48 Tahun 2005 yang menyatakan bahwa sejak ditetapkannya PP Nomor 48 Tahun 2005, semua Pejabat Pembina Kepegawaian dan pejabat lain di lingkungan instansi, dilarang mengangkat tenaga honorer atau yang sejenis, kecuali ditetapkan dengan Peraturan Pemerintah. Adanya larangan pengangkatan tenaga honorer atau pegawai Non PNS tersebut memberikan konsekuensi bagi satuan organisasi pusat maupun daerah untuk tidak mengangkat pegawai Non PNS atau tenaga honorer atau tenaga yang sejenisnya. Dengan mengabaikan jumlah PNS yang ada dan perhitungan kebutuhan pegawai secara ideal, sebenarnya di masingmasing satuan organisasi baik Pemerintah Daerah atau Pusat sebagian besar pertumbuhan jumlah PNS atau pegawainya adalah minus atau dengan kata lain minus growth, hal ini disebabkan karena setiap tahunnya perbandingan jumlah PNS atau pegawai yang keluar (karena mutasi, pensiun, atau meninggal dunia) selalu lebih besar dibandingkan dengan jumlah PNS atau pegawai yang masuk (karena terbatasnya jumlah formasi CPNS yang diberikan oleh pemerintah pusat). Sulitnya memenuhi 
lowongan formasi melalui jalur CPNS, disadari atau tidak satuan organisasi tentunya membutuhkan tambahan pegawai yang hanya dimungkinkan melalui pengadaan pegawai non PNS. Hal inilah yang kemudian menjadikan adanya larangan pengangkatan pegawai Non PNS melalui PP Honorer menjadi kurang bertaji dan cenderung tidak ditaati oleh Satuan Organisasi baik pusat maupun daerah. Tidak adanya sanksi yang jelas bagi satuan organisasi yang melaksanakan pengangkatan pegawai non PNS atau tenaga honorer juga menjadikan banyak satuan organisasi memilih untuk tetap melaksanakan pengadaan pegawai non PNS atau tenaga honorer dengan dalih untuk mengisi kekurangan pegawai yang tidak dapat diisi melalui formasi CPNS (Pujiraharjo, 2015).

Pasal 99 PP Nomor 49 Tahun 2018 tentang PPPK mengatur bahwa terhadap pegawai non-PNS (tenaga honorer atau sebutan lain) yang telah bertugas, masih tetap melaksanakan tugas paling lama 5 (lima) tahun. Apabila telah berakhir masa penugasannya/kontraknya dan tenaganya masih dibutuhkan maka dapat diperpanjang penugasannya/kontraknya dan/atau diangkat kembali dengan menetapkan surat keputusan pengangkatan kembali/perpanjangan perjanjian kontrak. Sedangkan apabila tenaganya tidak dibutuhkan karena akan/telah digantikan oleh CPNS/PNS/PPPK maka pegawai non-PNS tersebut dapat diberhentikan. Dalam jangka waktu paling lama 5 (lima) tahun (sampai dengan tahun 2023) tersebut pegawai nonPNS dapat diangkat menjadi PPPK apabila memenuhi persyaratan yang diatur dalam PP Nomor 49 Tahun 2018.

Kebijakan yang ditempuh pemerintah dalam mengatasi masalah tenaga honorer hingga tahun 2023 menurut Kepala BKN Bima Haria Wibisana adalah melalui beberapa cara yaitu: lewat jalur tes CPNS bagi tenaga honorer yang berusia di bawah 35 tahun, lewat jalur tes CPPPK bagi tenaga honorer yang berusia di atas 35 tahun. Bagi tenaga honorer yang tidak lulus tes CPNS maupun tes CPPPK, maka dikembalikan kepada daerah masing-masing dengan catatan gajinya harus setara dengan upah minimum regional (UMR), sedangkan bagi tenaga honorer non-kategori dapat mengikuti tes CPNS dan tes CPPPK melalui jalur umum (Jambiekspres, 2020). Berkaitan dengan hal tersebut itu maka terhadap tenaga honorer yang tidak lulus tes CPNS atau tes CPPPK masih tetap dapat dipekerjakan oleh pemerintah daerah dengan menggunakan dasar yuridis UU Nomor 13 Tahun 2003 tentang Ketenagakerjaan juncto UU Nomor 11 Tahun 2020 tentang Cipta Kerja. Tenaga kontrak dipekerjakan melalui skema hubungan kerja Perjanjian Kerja Waktu Tertentu (PKWT) atau melalui hubungan kerja dengan perusahaan alih daya. Kebijakan tersebut cukup memberikan keadilan bagi tenaga honorer yang selama ini telah bekerja di instansi Pemerintah dalam mewujudkan ketenangan dalam bekerja dan peningkatan penghasilan.

Mewujudkan ASN sebagai bagian dari reformasi birokrasi melalui UU Nomor 5 Tahun 2014 dan PP Nomor 49 Tahun 2018 berimbas pada penataan pegawai di instansi pemerintah. Gejolak sosial muncul terutama yang berasal dari para tenaga honorer sebagai reaksi atas implementasi peraturan perundang-undangan tersebut, namun birokrasi yang andal menjadi suatu kebutuhan masyarakat dan hal tersebut tidak dapat dinafikan oleh pemerintah sebagai penyelenggara pelayanan publik. Kebijakan pemerintah yang berkeadilan dalam penataan pegawai tetap diperlukan bagi tenaga honorer yang selama ini telah bekerja, namun birokrasi yang andal dan profesional merupakan suatu kebutuhan untuk mewujudkan good governance.

\section{Simpulan dan Saran}

Berdasarkan uraian dalam pembahasan, maka dapat disimpulkan hal-hal sebagai berikut: (1) ketersediaan SDM Aparatur yang andal menjadi faktor penting untuk memenuhi tuntutan masyarakat akan pelayanan publik yang cepat dan profesional. Untuk itu diperlukan adanya penataan birokrasi melalui reformasi 
birokrasi agar tercipta good governance dalam penyelenggaraan pemerintahan; (2) selama ini solusi keterbatasan jumlah SDM Aparatur PNS dilakukan melalui rekrutmen $\mathrm{PTT} /$ tenaga honorer oleh pejabat pemerintahan baik di pusat maupun daerah dengan menggunakan kewenangan diskresi; (3) lahirnya PP Nomor 49 Tahun 2018 tentang Manajemen PPPK membawa imbas atau dampak yang sangat signifikan yaitu Pejabat Pemerintahan tidak dapat lagi menggunakan kewenangan diskresi dalam perekrutan PTT/tenaga honorer, namun harus sesuai dengan kriteria yang ditentukan dalam peraturan perundang-undangan; (4) kebijakan penanganan tenaga honorer yang selama ini telah bekerja di instansi Pemerintah dalam penataan pegawai setelah lahirnya PP Nomor 49 Tahun 2018 tentang Manajemen PPPK dilakukan melalui rekrutmen CPNS dan CPPPK secara terbuka, bagi yang lolos seleksi dapat diangkat sebagai CPNS atau CPPPK, namun bagi yang tidak lolos tetap dapat dipekerjakan dengan menggunakan dasar yuridis UU Nomor 13 Tahun 2003 tentang Ketenagakerjaan juncto UU Nomor 11 Tahun 2020 tentang Cipta Kerja.

Selanjutnya, saran yang dapat diberikan adalah peraturan kebijakan sebagai pelaksanaan PP Nomor 49 Tahun 2018 hendaknya disusun secara konsisten dan tidak bertentangan dengan UU Nomor 5 Tahun 2014 dan PP Nomor 49 Tahun 2018, sehingga dapat memberikan kepastian peningkatan kesejahteraan dan menghindari ketidakpastian masa depan bagi tenaga honorer yang diangkat sebagai PPPK. Di sisi yang lain solusi terhadap tuntutan profesionalitas ASN juga dapat terpenuhi.

\section{DAFTAR PUSTAKA}

Abbas, F., \& Sadat, A. (2020). Model Pelayanan Publik Terhadap Reformasi Birokrasi. Jurnal Studi Ilmu Pemerintahan, 1(1), 16-25.

Badan Kepegawaian Negara. (2020). Buku Statistik PNS Juni 2020. Jakarta: Badan Kepegawaian Negara.
Darumurti, K. (2016). Diskresi Kajian Teori Hukum. Yogyakarta: Genta Publishing.

Faqir, A. Al. (2020). Pemerintah Catat Saat ini Ada 438.590 Pegawai Honorer, 35 Persennya Guru. Merdeka.Com.

Haning, M. T. (2018). Reformasi Birokrasi di Indonesia: Tinjauan Dari Perspektif Administrasi Publik. Jurnal Analisis Kebijakan Dan Pelayanan Publik, 4(1), 25-37.

Haryanto, J. T. (2015). Analisis Beban Fiskal Manajemen Pegawai Pemerintah Dengan Perjanjian Kerja Fiscal Burden Analysis for Non-Ongoing Employees Management. Jurnal Civil Service, 9(2), $1-12$.

Jambiekspres. (2020). Penjelasan Kepala BKN soal Honorer K2 dan Nonkategori, Lengkap! Jambiekspre. Jambi.

Juliani, H. (2018). Pertanggungjawaban Pejabat Pemerintahan Dalam Penggunaan Diskresi Yang Membebani Keuangan Negara. Administrative Law and Governance Journal, 1(3), 280298.

http://doi.org/10.14710/alj.v1i3.280-298

Juliani, H. (2019). Diskresi Dalam Rekrutmen Pegawai Non Pegawai Negeri Sipil Setelah Pemberlakuan Peraturan Pemerintah Nomor 49 Tahun 2018 tentang Manajemen Pegawai Pemerintah Dengan Perjanjian Kerja. Administrative Law and Governance Journal, 2(2), 314-325. http://doi.org/10.14710/alj.v2i2.314-325

Lohida, L. (2015). Analisis Komparasi Pegawai Pemerintah Dengan Perjanjian Kerja ( Pppk ) Dalam Paradigma Undang-Undang Nomor 5 Tahun 2014 Tentang Aparatur Sipil Negara Comparative Analysis of Non-Ongoing Employee From the Perspective of Law No . 5 Year 2014 About State App. Jurnal Civil Service, 9(2), 45-53.

Pujiraharjo, H. S. (2015). Pegawai Pemerintah dengan Perjanjian Kerja 
(Pppk): Solusi dalam Rekruitmen Pegawai dari Pegawai Non PNS ASN. Jurnal Civil Service, 9(2), 21-30.

Rahayu, A. Y. S., \& Juwono, V. (2019). Birokrasi \& Governance. Jakarta: Raja Grafindo Persada.

Ridwan H.R. (2014). Hukum Administrasi Negara. Jakarta: Raja Grafindo Persada.

Sihotang, G. A., Pujiyono, P., \& Sa'adah, N. (2017). Diskresi Dan Tanggung Jawab Pejabat Publik Pada Pelaksanaan Tugas Dalam Situasi Darurat. Law Reform, 13(1), 60-69. http://doi.org/10.14710/lr.v13i1.15951

Soemitro, R. (1994). Metodologi Penelitian Hukum dan Yurimetri. Jakarta: Ghalia Indonesia.

Susanto, S. N. H. (2019). Good Governance Dalam Konteks Hukum Administrasi. Administrative Law and Governance Journal, 2(2), 205-217. http://doi.org/10.14710/alj.v2i2.205-217

Wicaksono, K. (2014). Telaah Kritis Administrasi \& Manajemen Sektor Publik di Indonesia. Jakarta: Penerbit Gava Media. 